\title{
Teaching asthma first aid to pharmacy students: A comparative study between an online course and simulation by role-play
}

\author{
Dalia Bajis ${ }^{\text {iD }}$, Betty Chaar ${ }^{1}$, Iman Basheti², Rebekah Moles ${ }^{1}$ \\ 1 University of Sydney, Australia \\ ${ }^{2}$ Applied Science Private University, Jordan
}

\author{
Keywords \\ Active Learning \\ Asthma First Aid \\ Blended Learning \\ Competency-based Assessment \\ Pharmacy Education
}

\section{Correspondence}

Dalia Bajis

School of Pharmacy

Faculty of Medicine and Health

The University of Sydney

NSW 2006

Australia

dalia.bajis@sydney.edu.au

\begin{abstract}
Objective: To assess the impact of a bimodal workshop on pharmacy students' ability to perform asthma first aid (AFA) and their preferred method of learning. Method: Pharmacy students from the Applied Science University (ASU) in Amman, Jordan were invited to participate in an AFA training workshop, comprised of an online training course and simulation by role-play. Students were randomly allocated to one of two groups to start with either a simulation-based session or an interactive online course. After completion of the first session, groups were switched. Student ability to perform AFA was assessed by role-play using an AFA checklist. Students' preferences on methods of learning were investigated by evaluation forms and focus group discussion using a semi-structured survey. Results: Fifty students enrolled in the study, 35 (70\%) completed the evaluation forms on self-perceived confidence and overall satisfaction with the workshop. Performance in the role-played scenarios was not significantly correlated to whether students received the online training prior to assessment. Students ( $n=35,97 \%)$ agreed the AFA workshop increased their knowledge and confidence in managing a patient experiencing asthma exacerbation. When asked about their preferred method of learning, $77 \%$ stated a combination of online coursework and role-play. Conclusion: Students valued the novelty of combining learning methods, and hands-on training was perceived as necessary to consolidate knowledge into practice. Thus, blended learning was preferred by pharmacy students attending ASU in Jordan for learning how to perform AFA, and their performance was not affected by the mode of learning in this study.
\end{abstract}

\section{Introduction}

To date, asthma is the most prevalent chronic respiratory disease worldwide (GBD 2015 Chronic Respiratory Disease Collaborators, 2017). An estimated 235 million individuals worldwide are affected by asthma (World Health Organisation [WHO], 2020). Asthma is shown to be a global disease and deemed a significant public health problem affecting countries around the world (Nunes, Pereira, \& Morais-Almeida, 2017). Despite the great progress made in the healthcare community for understanding the patho- physiology of asthma, which led to innovative and effective pharmacological treatments, asthma remains a leading cause of preventable deaths (WHO, 2020). In the case of asthma management, patient education is vital (Kowalski, 2000). International asthma guidelines acknowledge asthma education as a key component of asthma management (Global Initiative for Asthma [GINA], 2020). In 2014, the UK National Review of Asthma Deaths reported two in three deaths from asthma could have been prevented (Torjesen, 2014). During a fatal asthma 
exacerbation, $45 \%$ of patients had not called for or obtained help until it was too late, and $70 \%$ of children and $83 \%$ of young people aged ten to 19 died before they reached hospital (Torjesen, 2014). Coupled with these findings, $77 \%$ of those who died had no evidence in their medical records of being provided with a Personal Asthma Action Plan (PAAP) detailing how their medication was to be taken, how to recognise danger signals, and when to call for help ( Torjesen, 2014; Levy, 2015). Similar findings were reported in Australia, where preventable or modifiable factors were identified in $70 \%$ of deaths attributed to asthma between 2005 and 2009 (Goeman et al., 2013).

Despite global disparities in its prevalence, low- and middle-income countries have shown a rising prevalence of asthma (Nunes, Pereira \& Morais-Almeida, 2017). In Jordan, asthma prevalence was estimated to be around $12 \%$ among the Jordanian population in general (Al Hroob, Nawafleh \& Altaif, 2016). Evidence points to poor management of the disease in Jordan and several deaths attributed to sub-optimal management (Al Hroob et al., 2016). Whilst there are no specific guidelines for the administration of Asthma First Aid in Jordan, the administration of a number of inhalations of a broncho-dilator is considered the appropriate management of an acute exacerbation until further help arrives if the episode requires. A recent study in Jordan reported that poor asthma control was associated with acute asthma exacerbation, with uncontrolled asthma patients more likely to have had at least one acute asthma exacerbation than controlled asthma patients over a 12-month period (Almomani et al., 2016). It was also highlighted that a majority of patients screened in the same study showed poor inhaler-use technique, and this was attributed to insufficient patient education (Almomani et al., 2016).

Administering asthma first aid (AFA) may help prevent an asthma exacerbation from progressing to an asthma emergency or even death. In Australia, the protocol of treatment for asthma exacerbation in the absence of a written PAAP includes the immediate provision of a shortacting beta agonist (SABA), keeping the person upright and calm, and calling an ambulance if symptoms are lifethreatening (severe shortness of breath, inability to speak comfortably or lips look blue) (National Asthma Council Australia, 2017; 2020). Other international protocols share the same basic principles for treatment of acute asthma exacerbation (National Heart Lung and Blood Institute, 2011; Asthma and Respiratory Foundation NZ, 2020; Asthma UK, 2020; Global Initiative for Asthma [GINA], 2020).

In pharmacy education, teaching and learning are designed to equip students with the knowledge, clinical skills, and professionalism required to deliver quality patient care (International Pharmaceutical Federation [FIP], 2020). One approach to encourage students to learn practical skills is via active learning, which involves actively immersing students in a range of diverse and imaginative activities in a safe environment (e.g. classroom) along with peers and instructors to 'think about what they are doing' (Stewart et al., 2011). Strategies of implementing active learning into pharmacy curricula are vast in number and have included simulation, problem-based learning, case studies, ability- and team-based learning, and online and flipped classroom formats that actively involve and engage students in the process of learning (Gleason et al., 2011; Stewart et al., 2011; Pierce \& Fox, 2012; Collier \& Baker, 2017). Active learning strategies have been utilised to teach pharmacy students practical skills necessary for professional practice such as physical examination (Seybert \& Barton, 2007; Ho et al., 2014), diabetes care (Wongwiwatthananukit et al., 2013), mental health first aid (O'Reilly et al., 2011), injection technique (Skoy, Eukel, \& Frenzel, 2013), and optimal medication use (Mehuys et al., 2008).

Educational interventions in asthma management are not rare, however, a review by Luckie et al. found no instrument had sufficient specific emphasis on acute asthma management or AFA (Luckie et al., 2018). Furthermore, there appears to be a gap in the literature on practice-based testing to assess knowledge and demonstration of skills required to manage acute asthma exacerbation (Luckie et al., 2018). Recently, final-year students' knowledge in providing AFA was compared preand post-education via an online training programme (Luckie et al., 2018). The study also evaluated the impact of online training on AFA skills performance and overall competency in the administration of AFA. Interestingly, this research concluded that online asthma management training was effective in increasing the knowledge needed for AFA, however, this knowledge did not translate into effective AFA skills, with only $29 \%$ of students deemed competent to save the life of a child in an asthma emergency (Luckie et al., 2018).

As the paradigm shift in instructional design continues to evolve, educators are further challenged to meet the learning needs of a technology-native millennial generation of students (Eagleton, 2017). The mode of learning is a topic of much debate amongst educators, but some suggest that the hybrid or blended mode (e.g. online instruction blended with face-to-face lectures) has a proven potential to enhance the effectiveness and efficiency of meaningful learning experiences (Garrison \& Kanuka, 2004). Within pharmacy education, this learning 
approach has received positive results for both student learning outcomes and satisfaction (Margolis, Porter \& Pitterle, 2017). Nonetheless, superiority of different instructional and learning modes remains undetermined. Findings from a 2015 review, evaluating the impact of online or blended learning vs. face-to-face learning of clinical skills in undergraduate education, agree with this uncertainty (McCutcheon et al., 2015). In this review, online learning for teaching clinical skills in nursing undergraduate education, for example, was not less effective than traditional methods, and further research into blended learning in teaching clinical skills was recommended (McCutcheon et al., 2015). What becomes critical is aligning assessment strategies with learning objectives and activities for optimising student outcomes (Biggs, 2003).

This study aimed to assess the impact of two active learning modalities (an online course and simulation by role-play) on pharmacy students' competency in performing AFA and explored students' preferred method of learning.

\section{Methods}

This research was approved by the University of Sydney Human Research Ethics Committee (HREC No. 2013/828, 2015/626), and informed consent was obtained from all participants. This study was conducted in March 2016 at the Faculty of Pharmacy, Applied Science Private University (ASU) - a private university in Amman, Jordan where a five-year Bachelor of Pharmacy is offered. The degree is taught in English and mandated courses represent three major disciplines: pharmaceutical sciences and pharmaceutics, pharmaceutical chemistry and pharmacognosy, and clinical pharmacy and therapeutics.

Pharmacy students enrolled in third-, fourth- and fifthyear Bachelor of Pharmacy degrees at ASU were conveniently sampled to participate in the workshop. Students were provided with verbal and written information about the aims and procedures of the research and requested to sign written consent forms. It was reiterated, prior to participation, that involvement was entirely voluntary and that participants could withdraw from the study without providing a reason and with no negative consequences.

A two-hour bimodal workshop was created by combining online and simulation (role-play) methods to constitute a hybrid or blended-style learning. No formal education on AFA was provided to students prior to this workshop. All participants received a ten-minute introduction to the aims and protocol of the workshop. Students were randomly allocated to one of two groups of 25 students to start with either a simulation-based session or an online interactive training session. The duration of the session for both groups was one hour. After completion of the first session, groups were switched to undergo the second modality of training.

Students in the simulation training group participated in a scenario-based interactive role-play session. Three subgroups of seven to nine students were formed. This workshop required students to role-play 'pharmacists' with one of three facilitators who role-played three different 'patients' experiencing exacerbation of asthma, respectively. Each group randomly selected a different student to role-play the pharmacist in each scenario, and this student was assessed on their performance. Hence, three students from each subgroup were assessed on their performance to administer AFA. The AFA assessment used hypothetical scenarios in which a child or adult experienced classic symptoms of acute asthma exacerbation (Appendix A), as defined by the Australian Asthma Guidelines (National Asthma Council Australia, 2020).

The AFA skills were scored using a checklist based on those used in previous studies (Appendix B) (Soo et al., 2017; Luckie et al., 2018). As indicated in previous research, the checklist was based on the Australian Resuscitation Council Guidelines (Australian Resuscitation Council, 2016). The Australian AFA training guidelines were deemed to be an appropriate training tool to use for pharmacy students in this study, based on the expertise of the research team since one author has expertise in asthma management in both Jordan and Australia, and two other authors have resided and worked in both Australia and Middle Eastern Countries. Equip-ment such as asthma medication placebos in various inhalation devices (Ventolin, Airomir, Seretide, Pulmicort) as well as spacers (Volumatic and Breath-A-Tech) were made available to students. Students were required to administer a SABA whilst keeping the patients upright and calm. In Scenario one, it was deemed necessary to call for an ambulance after round two of administering SABA with minimal improvement. In Scenario two, it was considered appropriate to contact an ambulance immediately as there was no previous history of asthma upon questioning the patient/caregiver. In the third scenario, after the patient recovered from breathlessness, it was deemed appropriate to advise the patient to visit his/her doctor to reassess his/her asthma management.

Immediate formative feedback and coaching were provided to the group of students by the facilitator after each role-play, guided by the marking rubric, pointing out 
aspects that were done well and criteria that were missed and the consequence of missing particular steps, whilst encouraging them to think of ways to improve their skills. Feedback included asking students about AFA steps, what AFA steps were not included in their performance and what he/she needed to do to improve their skill.

Furthermore, an overall competency score of pass or fail was given to each student. The minimum criterion was thought essential to 'save the life' of the patient described in each scenario, denoted by $X X$ in Appendix $B$. If the student scored below this level in those questions that had XX, then they failed the competency test. The maximum skills score was 24 points with two points for each correct response, one point for each partial response, and zero for an incorrect response or a complete lack of response. For example, selecting the wrong spacer size for 'spacer identified as required equipment' was considered a partial response. Students' overall ability was evaluated on their skills to administer AFA, and this competency score was used for this purpose and for guiding the feedback process.

For the online training group, students assembled in a computer laboratory at the university. The AFA online training module was hosted by Asthma Australia and had been developed as a training resource for all staff at schools and daycare centres (Asthma Australia, 2019). This online educational session of approximately 60-minute duration was comprised of a series of modules that included voiced-over slide sets with optional subtitles if the student wanted to read rather than listen to the audio, followed by quizzes to reinforce key messages. The main topics covered in this module were asthma facts, asthma management and asthma medications, as well as the management of an acute asthma exacerbation using AFA. An online certificate of completion was provided to participants only upon successful completion of the online modules. After students completed the online training session, the simulation-based training session was made available to them. Similarly, the online training session was made available for students who were first assigned to the simulation-based training group.

At the completion of the workshop, an evaluation of students' self-perceived confidence level was conducted. The six-item self-perceived confidence instrument used in this study had face and content validity and was previously used to measure changes in self-perceived confidence of pharmacy students (Schneider \& Moles, 2016). Students ranked their self-confidence on a five-point scale which ranged from strongly disagree to strongly agree. The learning tools/cases and rubrics used in Australia were reviewed by a Jordanian pharmacist who has extensive experience in asthma research in both Australia and Jordan.

Students' preferred learning method was explored using qualitative methods, which included a focus group and a semi-structured questionnaire. For the focus group, study participants were invited to attend a meeting immediately after the workshop concluded. The focus group was carried out with consenting students who were deidentified during data analysis. Focus groups are considered effective in generating collective participant feedback through a dynamic group interactive technique (Chang \& Hsu, 2006). Students were provided with a platform to share their opinions, perceptions and attitudes based on their experiences during the AFA workshop, hence, allowing the researchers to assess the overall impact of the workshop on student learning. Open-ended questions, which concentrated on exploring the perceived challenges and benefits of online- versus simulationbased learning in asthma first aid as an example of a practical skill, paralleled those in the course evaluation questionnaire. Interview questions included: Which way did you prefer to learn, online or simulation, and explain why? Which learning method do you prefer to experience first to improve your knowledge and why? How useful or not do you think the workshop was? and What challenges did you face in the workshop? The primary researcher in this study facilitated the focus group discussion with two researchers acting as moderators. In addition, a four-item questionnaire was developed with two additional openended questions to gather responses of students related to their experience with the two learning modalities (Appendix C). Data from qualitative methods were triangulated with quantitative results to validate findings obtained in this study (Anderson, 2010).

\section{Data analysis}

Quantitative data were analysed using Statistical Package for Social Sciences (SPSS) for Windows version 24 (Chicago, Illinois). Descriptive statistics were calculated for all relevant variables including students' demographic data. A normality test was conducted using the Kolmogorov-Smirnov test. The independent samples KruskalWallis test was used to compare mean scores for the three scenario groups. Level of significance for all analyses was set at an alpha equal to 0.05 .

The focus group was audio-recorded and later transcribed verbatim. All researchers checked transcripts for accuracy. The primary researcher used content analysis methods and inductively identified concepts that were coded, 
categorised data from students' responses, and formulated themes - a process by which the researcher made inferences about the messages within the texts of transcribed focus group interviews. The aim of content analysis is 'to attain a condensed and broad description of the phenomenon, and the outcome of the analysis is concepts or categories describing the phenomenon' (Elo \& Kyngäs, 2008: p. 108).

In preparation, the researcher immersed herself in the data to make sense of the data as a whole. Subsequent to immersion in the data, the primary researcher in this study organised the data by first dividing up the text into smaller parts with similar meaning, so-called meaning units (Erlingsson \& Brysiewicz, 2017). These meaning units were further 'condensed' while ensuring the core meaning was still retained. The next step was to label these ideas to formulate 'codes'. The formulated codes were then grouped to form 'categories'. Generating categories indicates assimilation of codes that are related to each other, and a category answers questions about: who, what, when, or where? This is an expression of manifest content, i.e. refers to the specific, clear, surface content in the data. In contrast, latent content analysis can be viewed as a deeper level of analysis and answers questions such as why, how, in what way, or by what means? i.e. refers to the underplaying meaning in the data. In this study, analysis was performed at the higher order of latent content, and themes were created. Table IV presents an example of an analysis schedule from raw data to results.

Data from focus groups were triangulated with responses of students to open-ended questions in the course evaluation questionnaire, which provided students with an opportunity to write down additional comments, suggestions, or areas of improvements. In triangulation, the use of multiple data methods or sources in qualitative research allows to develop a comprehensive understanding of the phenomena examined and test validity through the convergence of information from different sources (Carter et al., 2014). In this study, themes from the focus groups were triangulated with those elicited from student responses to the open-ended questions to provide an all-inclusive compilation of final themes capturing the views of a bigger number of students from the study.

To assure credibility and trustworthiness of qualitative data analysis (Patton, 1999), all codes, categories, and themes were initially identified by the primary researcher with experience in qualitative research and then verified by three other members of the research team. The process of constant iteration, that is constantly checking each code, category, and theme against the transcribed data collectively, was used to assure validity in the data interpretation (Morse et al., 2002). If a disagreement in the coding occurred, the researchers discussed the issue until resolution. Manifest-level themes were formulated first by the primary researcher. These were subsequently examined by three researchers for accuracy.

\section{Results}

A convenience sample was determined by the availability of students in the third-, fourth- and fifth-year cohorts of pharmacy students attending ASU invited to participate in the study.

Of the 50 students enrolled in the study, 35 (70\%) completed the evaluation forms on self-perceived confidence and overall satisfaction with the workshop. Of the 35 students, $80 \%(n=28)$ were female. Many of the participating students were in fifth-year $(n=15,43 \%)$, followed by students in fourth- $(n=13,37 \%)$ and third-year $(n=7,20 \%)$.

Eighteen students ( $n=50,36 \%)$ were randomly selected and assessed on their skills to perform AFA in the simulation session. This number of students was chosen for pragmatic reasons, as this was the maximum number that could be observed in the workshop timeframe available. Normality tests conducted using a KolmogorovSmirnov test on the total score of the AFA assessment obtained a significant result ( $p=0.015)$, hence, violating the assumption of normality in the sample of obtained scores. Students scored a mean skills assessment value of 17.1 (median $=19.0$ ). Overall, $33.3 \%$ of all assessed students were awarded a pass and deemed competent in handling an asthma exacerbation (Table I). A chi-square test for independence (with Yates' Continuity Correction) indicated no significant association between students' competence in AFA and educational intervention, with $X^{2}$ $(1, \mathrm{n}=18)=0.000, p=1.00$, $p h i=0.00$.

The distribution of mean scores was not significantly different across the three scenarios in the simulation arm. This was confirmed by a non-significant independent samples Kruskal-Wallis test $(p=0.55)$. Students had the lowest mean scores for skills related to calling an ambulance for the patients, recommending referral to a treating doctor (e.g. scenario three), and allowing for tidal breaths between SABA doses (Table II). 
Table I: Asthma first aid competency distribution by educational intervention

\begin{tabular}{lll}
\hline Educational intervention & Pass & Fail \\
\hline Simulation-based intervention* $(n=9)$ & $3(33.3 \%)$ & $6(66.7 \%)$ \\
Online-based intervention** $(n=9)$ & $3(33.3 \%)$ & $6(66.7 \%)$ \\
Total $(n=18)$ & $6(33.3 \%)$ & $12(66.7 \%)$ \\
\hline
\end{tabular}

* Students assessed on AFA before online-based training provided

${ }^{* *}$ Students assessed on AFA after online-based training provided

\section{Table II: Scenario checklist and mean scores}

\begin{tabular}{|c|c|c|}
\hline Step & Action & $\begin{array}{l}\text { Mean score } \\
\text { (SD) }\end{array}$ \\
\hline 1 & Sits patient upright, was calm and reassuring & $1.61(0.70)$ \\
\hline 2 & $\begin{array}{l}\text { Organises for an ambulance to be called } \\
\text { immediately OR organises to call ambulance } \\
\text { after child is provided with SABA** }\end{array}$ & $0.17(0.41)$ \\
\hline 3 & Correct medicine provided (SABA) & $2.00(0)$ \\
\hline 4 & Correct device selected (MDI) & $2.00(0)$ \\
\hline 5 & Spacer identified as required equipment*, ${ }^{* *}$ & $1.72(0.67)$ \\
\hline 6 & Inhaler shaken & $1.39(0.92)$ \\
\hline 7 & Inhaler inserted correctly & $1.56(0.71)$ \\
\hline 8 & $\begin{array}{l}\text { Single puffs of SABA provided (not multiple } \\
\text { puffs together) }\end{array}$ & $1.78(0.65)$ \\
\hline 9 & $\begin{array}{l}\text { Reported correct number of single puffs } \\
\text { appropriate for AFA }\end{array}$ & $1.33(0.91)$ \\
\hline 10 & $\begin{array}{l}\text { Allowed child tidal breaths ( } 4 \text { ) between SABA } \\
\text { puffs }\end{array}$ & $1.17(0.86)$ \\
\hline 11 & $\begin{array}{l}\text { Reported knowing to wait before starting } \\
\text { another round of SABA treatment ( } 4 \text { min) }\end{array}$ & $1.61(0.78)$ \\
\hline 12 & $\begin{array}{l}\text { Knew to call ambulance after } 2 \text { rounds of SABA } \\
\text { provided }^{*}\end{array}$ & $0.83(0.75)$ \\
\hline 13 & $\begin{array}{l}\text { Reported knowing to keep going with SABA } \\
\text { treatment while waiting for ambulance*, }{ }^{* *}\end{array}$ & $1.33(0.89)$ \\
\hline 14 & $\begin{array}{l}\text { Knew to monitor patient after exacerbation } \\
\text { and recommended referral to doctor }{ }^{* * *}\end{array}$ & $0.33(0.82)$ \\
\hline
\end{tabular}

SABA: short acting beta agonist, MDI: metered dose inhaler, AFA: asthma first aid

${ }^{*}$ required for scenario one

** required for scenario two

*** required for scenario three
Table III: Pharmacy students' ( $\mathrm{n}=35$ ) self-confidence ranking and preferred method of learning after completing AFA training

\begin{tabular}{|c|c|c|c|c|c|}
\hline $\begin{array}{l}\text { Student } \\
\text { confidence } \\
\text { ranking, } n(\%)\end{array}$ & $\begin{array}{l}\text { Strongly } \\
\text { Disagree }\end{array}$ & Disagree & $\begin{array}{l}\text { Un- } \\
\text { sure }\end{array}$ & Agree & $\begin{array}{l}\text { Strongly } \\
\text { Agree }\end{array}$ \\
\hline $\begin{array}{l}\text { Self-confidence } \\
\text { I feel... }\end{array}$ & & & & & \\
\hline $\begin{array}{l}\text { I have gained more } \\
\text { knowledge in the } \\
\text { steps to follow for } \\
\text { Asthma First Aid }\end{array}$ & & $\begin{array}{c}1 \\
(2.9)\end{array}$ & & $\begin{array}{c}7 \\
(20.0)\end{array}$ & $\begin{array}{c}27 \\
(77.1)\end{array}$ \\
\hline $\begin{array}{l}\text { Role-play based } \\
\text { scenarios helped } \\
\text { me understand } \\
\text { how to perform } \\
\text { Asthma First Aid }\end{array}$ & & & & $\begin{array}{c}8 \\
(22.9)\end{array}$ & $\begin{array}{c}27 \\
(77.1)\end{array}$ \\
\hline $\begin{array}{l}\text { Online learning is a } \\
\text { useful learning } \\
\text { tool }\end{array}$ & & $\begin{array}{c}1 \\
(2.9)\end{array}$ & $\begin{array}{c}3 \\
(8.6)\end{array}$ & $\begin{array}{c}17 \\
(48.6)\end{array}$ & $14(40)$ \\
\hline $\begin{array}{l}\text { If ever faced with a } \\
\text { situation, I am } \\
\text { more confident to } \\
\text { perform Asthma } \\
\text { First Aid }\end{array}$ & & & & $\begin{array}{c}12 \\
(34.3)\end{array}$ & $\begin{array}{c}23 \\
(65.7)\end{array}$ \\
\hline $\begin{array}{l}\text { The assessment } \\
\text { tasks challenged } \\
\text { me to learn }\end{array}$ & & $\begin{array}{c}3 \\
(8.6)\end{array}$ & $\begin{array}{c}3 \\
(8.6)\end{array}$ & $\begin{array}{c}13 \\
(37.1)\end{array}$ & $\begin{array}{c}16 \\
(45.7)\end{array}$ \\
\hline $\begin{array}{l}\text { I have been guided } \\
\text { by helpful } \\
\text { feedback on my } \\
\text { learning }\end{array}$ & & & $\begin{array}{c}1 \\
(2.9)\end{array}$ & $\begin{array}{c}15 \\
(42.9)\end{array}$ & $\begin{array}{c}19 \\
(54.3)\end{array}$ \\
\hline
\end{tabular}

Table IV: An example of an analysis schedule. Transcribed interviews with pharmacy students during focus group

\begin{tabular}{lllll}
\hline Meaning unit & $\begin{array}{l}\text { Condensed } \\
\text { meaning unit }\end{array}$ & Code & Category & Theme \\
\hline $\begin{array}{l}\text { I liked the inter- } \\
\text { active more than the } \\
\text { online work }\end{array}$ & $\begin{array}{l}\text { Likes inter- } \\
\text { active more }\end{array}$ & $\begin{array}{l}\text { Inter- } \\
\text { active }\end{array}$ & $\begin{array}{l}\text { Inter- } \\
\text { active } \\
\text { learning }\end{array}$ & $\begin{array}{l}\text { Active } \\
\text { learning }\end{array}$ \\
$\begin{array}{l}\text { Combination is } \\
\text { good. We were able } \\
\text { to under-stand and } \\
\text { apply knowledge }\end{array}$ & $\begin{array}{l}\text { Combination } \\
\text { is good, } \\
\text { understand } \\
\text { and apply }\end{array}$ & $\begin{array}{l}\text { Combi- } \\
\text { nation }\end{array}$ & $\begin{array}{l}\text { Combi- } \\
\text { ning } \\
\text { methods }\end{array}$ & $\begin{array}{l}\text { Blended } \\
\text { learning }\end{array}$ \\
\hline AFA: asthma first aid & & & & \\
\end{tabular}


Table V: Manifest level themes for the AFA course

\begin{tabular}{|c|c|c|}
\hline & $\begin{array}{l}\text { Manifest-level } \\
\text { themes }\end{array}$ & Example quotation \\
\hline \multirow{3}{*}{$\begin{array}{l}\text { Online } \\
\text { Experience }\end{array}$} & $(+)$ provides & 'I got the basic idea on asthma \\
\hline & knowledge base & $\begin{array}{l}\text { first aid from the online } \\
\text { training' [Student12] }\end{array}$ \\
\hline & $\begin{array}{l}\text { (-) lengthy online } \\
\text { course }\end{array}$ & $\begin{array}{l}\text { 'The online course should be } \\
\text { shorter...it took a long time' } \\
\text { [Student10] }\end{array}$ \\
\hline \multirow[t]{3}{*}{$\begin{array}{l}\text { Simulation } \\
\text { Experience }\end{array}$} & $\begin{array}{l}\text { (+) realistic way to } \\
\text { learn to and apply } \\
\text { knowledge }\end{array}$ & $\begin{array}{l}\text { 'Being put in situations that } \\
\text { makes you feel like you are } \\
\text { dealing with real } \\
\text { people' [Student 29] }\end{array}$ \\
\hline & $\begin{array}{l}(+) \text { hands on } \\
\text { experience }\end{array}$ & $\begin{array}{l}\text { 'Role-play made me feel more } \\
\text { confident for } \\
\text { practice' [Student24] }\end{array}$ \\
\hline & $\begin{array}{l}(+) \text { enjoyable way to } \\
\text { learn }\end{array}$ & $\begin{array}{l}\text { 'Definitely a new way to learn.. } \\
\text { it was very } \\
\text { exciting' [Student30] }\end{array}$ \\
\hline $\begin{array}{l}\text { Overall } \\
\text { Experience }\end{array}$ & $\begin{array}{l}(+) \text { combination of } \\
\text { methods is } \\
\text { complementary }\end{array}$ & $\begin{array}{l}\text { 'Combination of online and } \\
\text { role-play allows to understand } \\
\text { concepts and not forget } \\
\text { them' [Student06] }\end{array}$ \\
\hline
\end{tabular}

\section{Blended learning methods}

The majority of students identified 'blending' or 'combining' online training with simulation as an effective and efficient way to learn. They were perceived to 'complement' each other. Reasons for this preference included consolidation of knowledge and accommodation to various learning preferences/styles.

The order by which the two learning methods were preferred to be received yielded varied responses amongst students. Some students shared that performing the online training after exposure to simulation consolidated knowledge and skills learned in the role-play sessions and others felt it was equally effective vice versa. The idea that the two modalities worked in 'synergy' and 'better together' were common threads in responses:

I picked up the idea from the online course but in the simulation, I learnt a lot more ... We were able to understand and apply knowledge... Combination is good.'

[Focus group-student 2]

'During role-play, we saw exactly what we had to do and to try it out...the online modules gave us more information'.

[Written response-4]
Also, blended learning was considered accommodative of students' different learning styles. For some, who underwent training by simulation first, the experience revived previously-acquired knowledge on asthma management.

'I had some knowledge on asthma from pharmacology'.

[Focus group-student 13]

Despite a majority who felt daunted to act the role of pharmacists who were required to manage patients suffering from breathlessness, being novice actors enhanced their learning.

'When I did the live performance first, I remembered everything. If I did it the other way around, I wouldn't have remembered anything.'

[Written response-21]

However, a few reported the online course was needed to set the stage by providing knowledge on the guidelines and protocol of AFA before role-play.

'In the online course I took the knowledge... I had confidence to try it in the next session and apply it in a practical way.'

[Focus group-student 8]

Teaching using computer-based programs can be an efficient strategy, particularly because it can be delivered to a broad audience and offers flexibility to revisit learned content. Some students were in agreement with this.

'I prefer both [online and simulation] because online you can get the facts or instructions within minutes.'

[Focus group-student 5]

\section{Active learning opportunities}

Another key theme that emerged from students' comments was in relation to learning by simulation in the form of role-play. It was reported by many students that participating in the role-play scenarios was hands-on and felt 'realistic':

'Role-play scenarios made me feel I'm dealing with real patients... it felt so real...and how I should react to similar situations in the future.'

[Written response-7]

'This method [simulation by role-play] taught me how to use asthma inhalers.'

[Written response-8]

The level of interaction in the role-play sessions was highly valued by all students. There was a shared sense that through hands-on/role-play simulation students were 'getting closer to patients', bearing in mind that most 
students had limited face-to-face experience with real patients during their pharmacy training. Simulating patients by role-play formulated a closer encounter to 'patients' that boosted their self-confidence:

'The session during which we worked with you [simulation by role-play]... I got more confident...I learned how we are supposed to work in a pharmacy.... I liked the interactive work more than when we're behind computers... we need to learn to deal with patients...this has been better than just attending lectures which you are probably going to forget, whereas with the way you taught us will not be forgotten.'

[Focus group-student 1]

Immediate formative feedback and coaching after roleplay exercises was reported as advantageous and enhanced the learning process. One student reported:

'We received feedback right away... After watching the first role-play interaction, I felt I can manage the second one.'

[Focus group-student 11]

\section{Novelty in learning}

The overall learning experience was reported to be 'innovative' and 'exciting' which led many students to approve and encourage incorporating such strategies in the pharmacy curriculum. The workshop was perceived as a 'new' experience that was ideal to prepare students for practice:

'I want to really thank you because we attended many workshops before but this one is different... it's a creative way to give us a lot of information that is useful in daily practice...'

[Focus group-student 13]

I've gained more knowledge about asthma first aid and now I'm ready to perform it.'

[Focus group-14]

Moreover, participants' comments reflected the view that the learning opportunities offered to them during the workshop were largely dependent on the quality of teacher mentorship, especially where the facilitators (research team) created additional interactions and provided support. Adequate teacher support for innovative ways to teach was perceived as highly valuable:

'We need more of this amazing experience... teaching staff need to make [learning] more interesting... in fun ways sometimes... we need practical classes.'

[Written response-student 26]

\section{Discussion}

In this research, the authors created an interactive learning workshop that allowed pharmacy students in Jordan to acquire knowledge and practical skills in managing asthma exacerbation. Pharmacy students were introduced to AFA by a dual learning process: an online asthma management training package and by simulation in the form of role-play. Results highlighted that receiving the online training prior to simulation made no difference to the competency of pharmacy students in performing AFA. However, students preferred to experience a blended approach to their learning.

Through simulation-based assessment (pre or post undertaking online training), approximately one third of students in this study were deemed competent in managing asthma exacerbation. Despite disparity in sample size, this result coincides with the result reported by Luckie et al. of $29 \%$ ( $n=78$ ) of participants assessed as skilled to perform AFA post undertaking an online training module (Luckie et al., 2018). The authors suggested that the online format utilised in their study may only impart the 'know' component of Miller's pyramid (Miller, 1990) and that a scenario-based approach might be needed to supplement the learning process to facilitate achieving higher order skills - e.g. 'shows how' skills as more indicative of competence.

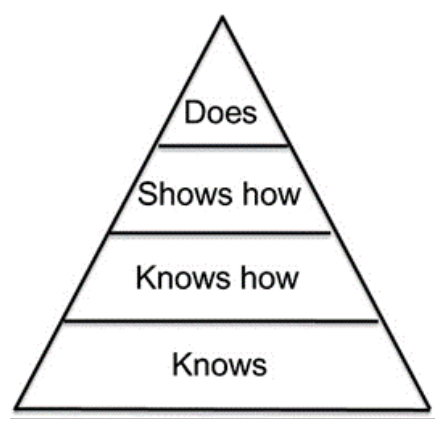

Figure A: Miller's Pyramid (1990) (Miller, 1990) displaying stages of learning a skill

Our goal as educators is to create meaningful practice situations that closely simulate real performance of the task or service required in real practice, as much as possible. As Miller proposes, to clinically assess students at the 'shows how' level, students ought to be adequately taught at the 'shows how' level (Figure A). This approach is also analogous with the constructive alignment theory proposed by Briggs and Tang in 2007, which explains the 
phenomenon of learning as that which is created just as much by the learner as by direct instruction alone (Biggs, 1999). Constructive alignment informs educators to view any educational programme as a 'whole system' that encompasses the curriculum, the teaching methods, and assessment procedures (Biggs, 1999). This theory can be used to underpin and inform skills development, such as the skill of AFA, whereby learning outcomes are identified first, followed by how to teach and assess these skills in the most active and student-centred way possible. In the case of AFA, knowledge acquisition on asthma management, proper device use, and administration of medications will be consolidated once this knowledge is applied in practice.

Consistent with findings previously reported in the literature, students in this study perceived that combining online training and simulation was beneficial (Margolis et al., 2017). Student satisfaction in learning processes has been formerly acknowledged as an important factor in order to estimate the effectiveness of a course, including blended learning (Giannousi et al., 2009). Whilst the majority of students nominated blended-style learning beneficial in AFA, there was no support for online-learning in isolation of role-play. Students emphasised that simulation-based training was important in terms of experiencing a pseudo patient-centred experience, and its benefits would be more 'long-lasting'. Bauer and Huynh and Kaveevivitchai et al. similarly reported results in favour of blended learning for performance and skill acquisition of nursing students compared with computerassisted learning alone (Bauer, Geront \& Huynh, 2001; Kaveevivitchai et al., 2009). However, evidence of learning method superiority to improve clinical competencies and their longevity remains limited and conflicting (Rowe, Frantz \& Bozalek, 2012; McCutcheon et al., 2015).

With the explosion of technology in simulation, the opportunity to teach pharmacy students has also almost limitless boundaries, allowing for human patient simulation and virtual reality (Jacklin, Maskrey \& Chapman, 2018). Simulation-based training has offered multiple advantages to reduce risk to patients and learners and improve learners' competence and confidence (Al-Elq, 2010). In its simplest form, this type of experiential learning is considered learning by doing, one that immerses learners in an experience and then encourages reflection about the experience to develop new skills, new attitudes, or new ways of thinking (Lewis \& Williams, 1994). In relation to asthma specifically, the study of Thoumas-Shehata et al. on factors affecting pharmacy students' maintenance of inhaler device technique, identified the strongest determinant of inhaler technique maintenance was experience with showing patients how to use asthma inhalers, emphasising that practice and repetition will further enhance the learning experience (Toumas-Shehata et al., 2018).

One other pivotal aspect that enhanced the active learning experience of students was receiving immediate formative feedback and coaching on their performance of AFA. That is 'to communicate information to the learner that is intended to modify his or her thinking or behaviour for the purpose of improving learning - formative feedback' (Shute, 2008: p.154). Formative feedback was crucial to improving knowledge and skill acquisition of learners and to not merely measure performance. Students in this study indicated that by receiving immediate feedback, they were able to understand the steps of AFA more effectively. Research on formative feedback and its relation to learning and performance is copious (Shute, 2008). Feedback that is delivered correctly has a significant role in motivating learners, and this was particularly pertinent in this study due to the fact that students were novice learners in AFA. Feedback and coaching in this case emphasised that making mistakes is part of the learning acquisition process as well as acted as a pedagogical tool to scaffold higher order thinking. Students were provided with an opportunity to construct their own knowledge anchored by prior observation of peers performing the task, and this was a novelty in their own learning experience.

Pharmacists can play an important role in Jordan, reversing preventable factors by educating patients about correct inhaler technique and managing asthma exacerbation. As competency-based pharmacy training and assessment underpin the pharmacy profession and practice, schools of pharmacy in Jordan and neighbouring countries are also charged with facilitating locally-tailored and innovative educational opportunities (Bajis et al., 2016; Almaghaslah et al., 2018; Bajis, Moles \& Chaar, 2018; Cheema, 2018; Bajis et al., 2019).

\section{Strengths and limitations}

There are potential limitations to this study. With respect to students' self-perceived confidence, the authors did not conduct a pre/post-intervention comparison. Even though this might be considered more useful than just the postintervention assessment, this was not the intention of this study. Post-intervention assessment was utilised as an informative tool to identify students' perceptions of undertaking the workshop to encourage self-reflection and to triangulate data uncovered in the focus group. 
All students in the study attended the online training session, but due to time constraints and the limited number of trained facilitators only a small sample size was utilised for the actual performance assessment. This could be another limitation that could impact the robustness of results. However, the authors believe observer-students were able to learn through observation and the feedback their fellow colleagues were given by them and the facilitator (Boukouvalas et al., 2018).

Language barriers could also have contributed to students' lack of understanding to questions presented in the evaluation forms, students' lack of confidence to communicate in English during role-play, and possibly students' fear of expressing their thoughts and opinions, thus affecting data collected. However, as previously stated, three of the researchers being fluent in Arabic, were able to translate when needed.

\section{Conclusion}

In this study, pharmacy students preferred learning practical skills when the instruction was designed to provide experiences that involved interactions with other individuals, doing or practicing particular skills, and provided opportunities for feedback to enhance performance. Therefore, training future pharmacists to be able to respond to various situations they might encounter in their professional practice, such as performing AFA, is crucial to their development as competent healthcare providers. It is by positioning students at the core of the learning process, that educators can create an environment where learning can occur and flourish. It can be argued that in a new world of education that is highly driven by an upsurge of technology and advancement in innovative pursuits, hands-on learning in health education, especially with real patients, remains invaluable.

\section{Acknowledgements}

The authors gratefully acknowledge the administrators and academics at the Faculty of Pharmacy, Applied Sciences University, Amman Jordan, whose contribution in facilitating student data collection made this study possible. The authors are also very grateful to all students who participated in this study and shared their opinions and thoughts.

\section{References}

Al-Elq, A.H. (2010). Simulation-based medical teaching and learning. Journal of Family and Community Medicine, 17(1), 35-40. https://doi.org/10.4103/1319-1683.68787

Al Hroob, A.M., Nawafleh, H., \& Altaif, K.I. (2016). Population Prevalence of Asthma in Ma'an Governorate, Jordan. Health Science Journal, 10(2:1)

Almaghaslah, D., Ghazwani, M., Alsayari, A., \& Khaled, A. (2018). Pharmacy students' perceptions towards online learning in a Saudi pharmacy school. Saudi Pharmaceutical Journal, 26(5), 617-621. https://doi.org/10.1016/i.jsps.2018.03.001

Almomani, B.A., Al-Sawalha, N.A., Samrah, S.M., Gamble, J.M., \& Al Momani, M.A. (2016). Asthma insights from Jordan: crosssectional observational study. Journal of Asthma, 53(4), 349-355. https://doi.org/10.3109/02770903.2015.1121493

Anderson, C. (2010). Presenting and Evaluating Qualitative Research. American Journal of Pharmaceutical Education, 74(8). https://doi.org/10.5688/aj7408141

Asthma and Respiratory Foundation NZ. (2020). Asthma First Aid (online). Available at: https://www.asthmafoundation.org.nz/ your-health/living-with-asthma/asthma-first-aid

Asthma Australia. (2019). Asthma First Aid For Schools-2020 (online). Available at: https://asthmaonline.org.au/product/ asthma-first-aid-for-schools/

Asthma UK (2020). Asthma Attacks (online). Available at: https:// www.asthma.org.uk/advice/asthma-attacks/

Australian Resuscitation Council. (2016). First aid for Asthma ANZCOR guideline 9.2.5 (online). Available at: https:// resus.org.au/guidelines/

Bajis, D., Chaar, B., Penm, J., \& Moles, R. (2016). Competencybased pharmacy education in the Eastern Mediterranean Region - A scoping review. Currents in Pharmacy Teaching and Learning, 8(3), 401-428. https://doi.org/10.1016/j.cptl.2016.02.003

Bajis, D., Chaar, B., Basheti, I.A., \& Moles, R. (2019). Pharmacy students' medication history taking competency: Simulation and feedback learning intervention. Currents in Pharmacy Teaching and Learning, 11(10), 1002-1015. https://doi.org/10.1016/ j.cptl.2019.06.007

Bajis, D., Moles, R., \& Chaar, B. (2018). Stakeholders' perspectives on quality assurance of pharmacy education in the Eastern Mediterranean Region. American Journal of Pharmaceutical Education, 82(10), 1209-1223. https://doi.org/10.5688/ajpe6482

Bauer, M., Geront, M., \& Huynh, M. (2001). Teaching blood pressure measurement: CD-ROM versus conventional classroom instruction. Journal of Nursing Education, 40(3), 138-141 
Biggs, J. (1999). Teaching for Quality Learning at University. Society for Research in Higher Education and Open University Press, Buckingham

Biggs, J. (2003). Aligning teaching for constructing learning. Higher Education Academy, York

Boukouvalas, E.A., El-Den, S., Chen, T.F., Moles, R., Saini, B., Bell, A., \& O'Reilly, C.L. (2018). Confidence and attitudes of pharmacy students towards suicidal crises: patient simulation using people with a lived experience. Social Psychiatry and Psychiatric Epidemiology, 53(11), 1185-1195. https://doi.org/10.1007/ s00127-018-1582-2

Carter, N., Bryant-Lukosius, D., DiCenso, A., Blythe, J., \& Neville, A.J. (2014). The use of triangulation in qualitative research. Oncology Nursing Forum, 41(5), 545-547. https://doi.org/ $\underline{10.1188 / 14.0 N F .545-547}$

Chang, M.Y., \& Hsu, L.L. (2006). Qualitative research: an introduction to focus group methodology and its application. $\mathrm{Hu}$ Li Za Zhi. Journal of Nursing, 53(2), 67-72

Cheema, E. (2018). The need to introduce simulation-based teaching in pharmacy education in Saudi Arabia. Pharmacy, 6(3). https://doi.org/10.3390/pharmacy6030060

Collier, I.A., \& Baker, D.M. (2017). Creation of an active learning healthcare communications course using simulations relevant to pharmacy practice. Currents in Pharmacy Teaching and Learning, 9(4), 626-632. https://doi.org/10.1016/i.cptl.2017.03.012

Eagleton, S. (2017). Designing blended learning interventions for the 21st century student. Advances in Physiology Education, 41(2), 203-211. https://doi.org/10.1152/advan.00149.2016

Elo, S., \& Kyngäs, H. (2008). The qualitative content analysis process. Journal of Advanced Nursing, 62(1), 107-115. https:// doi.org/10.1111/j.1365-2648.2007.04569.x

Erlingsson, C., \& Brysiewicz, P. (2017). A hands-on guide to doing content analysis. African Journal of Emergency Medicine, 7(3), 93-99. https://doi.org/10.1016/i.afjem.2017.08.001

Garrison, D.R., \& Kanuka, H. (2004). Blended learning: uncovering its transformative potential in higher education. The Internet and Higher Education, 7(2), 95-105. https://doi.org/ 10.1016/i.iheduc.2004.02.001

GBD 2015 Chronic Respiratory Disease Collaborators. (2017). Global, regional, and national deaths, prevalence, disabilityadjusted life years, and years lived with disability for chronic obstructive pulmonary disease and asthma, 1990-2015: a systematic analysis for the global burden of disease study 2015. Lancet Respiratory Medicine, 5(9), 691-706. https://doi.org/ $\underline{10.1016 / S 2213-2600(17) 30293-X}$

Giannousi, M., Vernadakis, N., Derri, V., Michalopoulou, M., \& Kioumourtzoglou, E. (2009). Students' satisfaction from blended learning instruction. Proceedings of the TCC Worldwide Online Conference, 1, 61-68
Gleason, B.L., Peeters, M.J., Resman-Targoff, B.H., Karr, S., McBane, S., Kelley, K., Thomas, T., \& Denetclaw, T.H. (2011). An active-learning strategies primer for achieving ability-based educational outcomes. American Journal of Pharmaceutical Education, 75(9). https://doi.org/10.5688/aipe759186

Global Initiative for Asthma (GINA). (2020). Global strategy for asthma management and prevention (online). Available at: https://ginasthma.org

Goeman, D.P., Abramson, M.J., McCarthy, E.A., Zubrinich, C.M., \& Douglass, J.A. (2013). Asthma mortality in Australia in the 21st century: a case series analysis. BMJ Open, 3(5). https://doi.org/ $\underline{10.1136 / \text { bmjopen-2012-002539 }}$

Ho, J., Bidwal, M.K., Lopes, I.C., Shah, B.M., \& Ip, E.J. (2014). Implementation of an accelerated physical examination course in a doctor of pharmacy program. American Journal of Pharmaceutical Education, 78(10). https://doi.org/10.5688/ajpe7810182

International Pharmaceutical Federation. (2020). Strategic Plan 2019-2024. The Hague, NETH (online). Available at: https:// www.fip.org/file/4369

Jacklin, S., Maskrey, N., \& Chapman, S. (2018). Improving shared decision making between patients and clinicians: design and development of a virtual patient simulation tool. JMIR Medical Education, 4(2). https://doi.org/10.2196/10088

Kaveevivitchai, C., Chuengkriankrai, B., Luecha, Y., Thanooruk, R., Panijpan, B., \& Ruenwongsa, P. (2009). Enhancing nursing students' skills in vital signs assessment by using multimedia computer-assisted learning with integrated content of anatomy and physiology. Nurse Education Today, 29(1), 65-72. https:// doi.org/10.1016/i.nedt.2008.06.010

Kowalski, A.F. (2000). Reducing asthma morbidity and mortality. Cost containment strategies. American Association of Occupational Health Nurses, 48(9), 418-422. https://doi.org/ $\underline{10.1177 / 216507990004800902}$

Levy, M.L. (2015). The national review of asthma deaths: what did we learn and what needs to change? Breathe, 11(1), 14-24. https://doi.org/10.1183/20734735.008914

Lewis, L.H., \& Williams, C.J. (1994). Experiential learning: Past and present. New Directions for Adult and Continuing Education, 1994(62), 5-16. https://doi.org/10.1002/ace.36719946203

Luckie, K., Pang, T.C., Kritikos, V., Saini, B., \& Moles, R.J. (2018). Systematic review and content analysis of asthma knowledge questionnaires: A focus on the knowledge surrounding acute exacerbation management. Journal of Asthma, 55(6), 615-628. https://doi.org/10.1080/02770903.2017.1355380

Luckie, K., Saini, B., Galstaun, V., Kritikos, V., Collins, J.C., \& Moles, R.J. (2018). The effectiveness of an online training programme to prepare teachers to provide asthma first aid. Journal of Paediatrics and Child Health, 54(12), 1348-1352. https://doi.org/ 10.1111/jpc.14080 
Luckie, K., Saini, B., Soo, Y.Y.B., Kritikos, V., Collins, J.C., \& Moles, R.J. (2018). Impact of scenario based training on asthma first aid knowledge and skills in school staff: an open label, three-arm, parallel-group repeated measures study. Journal of Asthma, 56(9), 973-984. https://doi.org/10.1080/02770903. $\underline{2018.1508471}$

Margolis, A.R., Porter, A.L., \& Pitterle, M.E. (2017). Best practices for use of blended learning. American Journal of Pharmaceutical Education, 81(3), 1-8. https://doi.org/10.5688/ajpe81349

McCutcheon, K., Lohan, M., Traynor, M., \& Martin, D. (2015). A systematic review evaluating the impact of online or blended learning vs. face-to-face learning of clinical skills in undergraduate nurse education. Journal of Advanced Nursing, 71(2), 255-270. https://doi.org/10.1111/jan.12509

Mehuys, E., Van Bortel, L., De Bolle, L., Van Tongelen, I., Annemans, L., Remon, J.P., \& Brusselle, G. (2008). Effectiveness of pharmacist intervention for asthma control improvement. European Respiratory Journal, 31(4), 790-799. https://doi.org/ $\underline{10.1183 / 09031936.00112007}$

Miller, G.E. (1990). The assessment of clinical skills/competence/ performance. Academic Medicine, 65(9), 63-67. https://doi.org/ $\underline{10.1097 / 00001888-199009000-00045}$

Morse, J.M., Barrett, M., Mayan, M., Olson, K., \& Spiers, J. (2002). Verification strategies for establishing reliability and validity in qualitative research. International Journal of Qualitative Methods, 1(2), 13-22. https://doi.org/10.1177/ $\underline{160940690200100202}$

National Asthma Council Australia. (2017). Asthma first aid (online). Available at: https://www.nationalasthma.org.au/ asthma-first-aid

National Asthma Council Australia. (2020). Australian Asthma Handbook. Available at: http://www.asthmahandbook.org.au/

National Heart Lung and Blood Institute. (2011). Management of asthma exacerbations: school treatment suggested emergency nursing protocol for students with asthma symptoms who don't have a personal asthma action plan (online). Available at: https://www.nhlbi.nih.gov/files/docs/resources/lung/sch-emeractplan.pdf

Nunes, C., Pereira, A.M., \& Morais-Almeida, M. (2017). Asthma costs and social impact. Asthma Research and Practice, 3(1), 1-11. https://doi.org/10.1186/s40733-016-0029-3

O'Reilly, C.L., Bell, J.S., Kelly, P.J., \& Chen, T.F. (2011). Impact of mental health first aid training on pharmacy students' knowledge, attitudes and self-reported behaviour: a controlled trial. Australian and New Zealand Journal of Psychiatry, 45(7), 549-557. https://doi.org/10.3109/00048674.2011.585454

Patton, M.Q. (1999). Enhancing the quality and credibility of qualitative analysis. Health Services Research, 34(5:2), 1189-1208
Pierce, R., \& Fox, J. (2012). Vodcasts and active-learning exercises in a "flipped classroom" model of a renal pharmacotherapy module. American Journal of Pharmaceutical Education, 76(10), 196. https://doi.org/10.5688/ajpe7610196

Rowe, M., Frantz, J., \& Bozalek, V. (2012). The role of blended learning in the clinical education of healthcare students: a systematic review. Medical Teacher, 34(4), 216-221. https:// doi.org/10.3109/0142159X.2012.642831

Schneider, C., \& Moles, R. (2016). Walking in consumers' shoes: reshaping the pharmacy student placement curriculum via mystery shopping with feedback (online). Available at: https:// Itr.edu.au/resources/SD14 4207 Schneider Report 2016.pdf

Seybert, A.L., \& Barton, C.M. (2007). Simulation-based learning to teach blood pressure assessment to doctor of pharmacy students. American Journal of Pharmaceutical Education, 71(3), 48. https://doi.org/10.5688/aj710348

Shute, V.J. (2008). Focus on formative feedback. Review of educational research, 78(1), 153-189. https://doi.org/10.5688/ aj710348

Skoy, E.T., Eukel, H.N., \& Frenzel, J.E. (2013). Comparison of lowand higher-fidelity simulation to train and assess pharmacy students' injection technique. American Journal of Pharmaceutical Education, 77(2). https://doi.org/10.5688/ ajpe 77233

Soo, Y.Y., Luckie, K.H., Saini, B., Kritikos, V., Brannan, J.D., \& Moles, R.J. (2017). Improving childcare staff management of acute asthma exacerbation - An Australian pilot study. Journal of Asthma, 54(7), 732-740. https://doi.org/10.1080/027709 $\underline{03.2016 .1258076}$

Stewart, D.W., Brown, S.D., Clavier, C.W., \& Wyatt, J. (2011). Active-learning processes used in US pharmacy education. American Journal of Pharmaceutical Education, 75(4). https:// doi.org/10.5688/ajpe75468

Torjesen, I. (2014). Two thirds of deaths from asthma are preventable, confidential inquiry finds. BMJ, 348. https://doi.org/ 10.1136/bmi.g3108

Toumas-Shehata, M., Henricks, M., Ovchinikova, L., Smith, L., \& Bosnic-Anticevich, S. (2018). Teaching pharmacy undergraduate students inhaler device technique and exploring factors affecting maintenance of technique. Canadian Respiratory Journal. https://doi.org/10.1155/2018/1597217

Wongwiwatthananukit, S., Zeszotarski, P., Thai, A., Fuller, R., Owusu, Y., Tan, C., Gomez, L., \& Holuby, S. (2013). A training program for pharmacy students on providing diabetes care. American Journal of Pharmaceutical Education, 77(7). https:// doi.org/10.5688/ajpe777153

WHO [World Health Organisation]. (2020). Asthma (online). Available at: http://www.who.int/news-room/fact-sheets/detail/ asthma 


\section{Appendices}

\section{Appendix A}

\section{Scenarios used in the asthma first aid workshop}

Scenario one - Child exacerbation of asthma

You are a pharmacist working in a community pharmacy. A lady runs into the pharmacy saying: 'Please help me, my nephew is having an asthma attack, and I'm not sure what to do. He is 7 years old, I know he has SABA at home which I think his mum gives him only when he is breath-less. I've taken him out today and I don't have a puffer on me.'

Notes: Child is not sure on what his action plan says but he knows that he has one.

\section{Scenario two - Undiagnosed child}

You are a pharmacist working in a community pharmacy. A customer runs into the pharmacy saying: 'Please help me, my 5-year-old daughter seems to be having trouble breathing. She had some croup last night and was coughing a lot but this morning I thought she was ok. I was walking to the shops with her and my dog, and she and the dog ran ahead. When I caught up with her, I found her sitting on the footpath and looking like this.'

Notes: Child can't talk in sentences; she is looking really unwell, she can't breathe. Child has never had a diagnosis of asthma; she has had croup before which which the GP prescribed prednisolone liquid. She is not allergic to anything that mum knows of. The child does not completely improve after two rounds of SABA to see if they know to keep going.

\section{Scenario three - Adult exacerbating of asthma}

You are a pharmacist working in a community pharmacy. A customer walks into the pharmacy with very little breath saying: 'Please help me, I can't breathe. Had asthma as kid, moving house help. Can't remember what to do.'

Notes: Patient gets better after first round of SABA

\section{Appendix B: Scenario one checklist}

\begin{tabular}{|c|c|c|c|c|}
\hline Step & Action & $\begin{array}{l}\text { Yes } \\
(2)\end{array}$ & $\begin{array}{l}\text { Partial } \\
\text { (1) }\end{array}$ & $\begin{array}{l}\text { No } \\
(0)\end{array}$ \\
\hline 1 & Sits child upright, was calm and reassuring & $X X$ & & \\
\hline 2 & Correct medicine selected & $X X$ & & \\
\hline 3 & Correct device selected & $X X$ & & \\
\hline 4 & Spacer identified as required equipment & $X X$ & $X X$ & \\
\hline 5 & Inhaler shaken & & & \\
\hline 6 & Inhaler inserted correctly into spacer & $X X$ & & \\
\hline 7 & $\begin{array}{l}\text { Single puffs of SABA provided (not multiple } \\
\text { puffs altogether) }\end{array}$ & $X X$ & & \\
\hline 8 & $\begin{array}{l}\text { Reported correct number of single puffs of } \\
\text { SABA appropriate for asthma first aid (4) }\end{array}$ & $X X$ & $X X$ & \\
\hline 9 & $\begin{array}{l}\text { Allowed child tidal breaths between SABA } \\
\text { puffs (4) }\end{array}$ & $X X$ & $X X$ & \\
\hline 10 & $\begin{array}{l}\text { Reported knowing to wait before starting } \\
\text { another round of SABA treatment (four } \\
\text { minutes) }\end{array}$ & $X X$ & $X X$ & \\
\hline 11 & $\begin{array}{l}\text { Knew to call the ambulance after two } \\
\text { rounds of SABA provided }\end{array}$ & $X X$ & & \\
\hline 12 & $\begin{array}{l}\text { Reported knowing to keep going with SABA } \\
\text { treatment while waiting for ambulance }\end{array}$ & $X X$ & & \\
\hline
\end{tabular}

XX: Minimum requirement needed to score a pass in the competency assessment

Appendix C: Student evaluation questionnaire of workshop

\begin{tabular}{|c|c|c|c|c|c|}
\hline I believe that... & $\begin{array}{l}\text { Strongly } \\
\text { Disagree }\end{array}$ & $\begin{array}{l}\text { Dis- } \\
\text { agree }\end{array}$ & $\begin{array}{l}\text { Unde- } \\
\text { cided }\end{array}$ & Agree & $\begin{array}{l}\text { Strongly } \\
\text { Agree }\end{array}$ \\
\hline $\begin{array}{l}\text { Role-play exercises were } \\
\text { useful in reinforcing con- } \\
\text { cepts learned previously in } \\
\text { the pharmacy course }\end{array}$ & & & & & \\
\hline $\begin{array}{l}\text { Receiving immediate } \\
\text { feedback on performance }\end{array}$ & & & & & \\
\hline was useful to improve & & & & & \\
\hline knowledge and skills & & & & & \\
\hline $\begin{array}{l}\text { Peer review was a useful } \\
\text { technique to receive } \\
\text { feedback on performance }\end{array}$ & & & & & \\
\hline $\begin{array}{l}\text { The workshop has } \\
\text { improved my ability to } \\
\text { perform Asthma First Aid }\end{array}$ & & & & & \\
\hline
\end{tabular}

